\title{
Pre-Columbian Tuberculosis in Tierra del Fuego? Discussion of the Paleopathological and Molecular Evidence.
}

\author{
Guichón, Ricardo A.(1); Buikstra, Jane E.(2); Stone, Anne C. (2); Harkins, Kelly M. (2); Suby, \\ Jorge A. (1); Massone, Mauricio (3); Prieto Iglesias, Alfredo (4); Wilbur, Alicia (5) \\ Constantinescu, Florence (6); Rodríguez Martín, Conrado (7)
}

Keywords: Tuberculosis, Ancient DNA, Tierra del Fuego, Bioarchaeology

\section{Introduction and background}

Tuberculosis (TB) is an infectious disease whose origin and co-evolutionary relationships with $\mathrm{H}$. sapiens are subjects of ongoing debate (Comas et al. 2013, Hershberg et al. 2008, Hershkovitza et al. 2015, Gagneux 2012, Pálfi et al. 2015, Roberts and Buikstra 2003, Stone et al. 2009, Wirth et al. 2008). Any such discussion of human-pathogen co-evolution must consider TB's global dispersion and the variety of vectors that can transmit it. Addressing this complex scenario requires the collaboration of paleopathologists, epidemiologists, microbiologists, immunologists, bioarchaeologists, zooarchaeologists, and historians. Cold regions, with their potential for preserving bone and / or soft tissue, as well as preservation of ancient DNA, are especially auspicious sites for this form of paleopathological study. Our focus here is on the "Island of Tierra del Fuego" where there is preliminary bioarchaeological evidence of TB.

The long-term goal of our research program is to explore the molecular nature of TB in Tierra del Fuego, before and after the arrival of Europeans. Importantly, during the late 19th and during the 20th century, with the development of the first urban centers in southern Patagonia, TB was the leading cause of death in the Rio Grande valley, as recorded for Ushuaia in Argentina and Punta Arenas in Chile (Casali 2013). 
In 1999, Constantinescu briefly described vertebral bone lesions compatible with TB in a skeleton from the Myren 1 site (Fig. 1), excavated by the archaeologist Massone. Although there was no radiocarbon dating of the human remains at that time, Massone attributed this site to a pre-European contact period (Massone et al 1999). In 1995, as part of a collaborative project between teams from Spain, Argentina, and Chile, the D haplogroup was identified for this individual, which corresponds with haplotypes common for native peoples in this region (Lalueza 1995, Lalueza et al 1997).

Clinical models describe a low frequency of bone involvement as a result of disseminated TB, usually associated with destructive lesions in the spinal column and appendicular skeleton, and occasionally in the skull (Resnick and Niwayama 1995). New bone formation on the pleural surfaces of ribs is considered suggestive but not pathognomomic for tTB (Roberts and Buikstra 2003; Santos and Suby 2012).

Analyses of ancient DNA have been used to investigate the causative agent of the observed TB bone lesions in South America since the 1990s (Arriaza et al 1995; Salo et al 1994). These early studies recovered and amplified ancient DNA from the $M$. tuberculosis complex (MTBC), which was inferred to have been most closely related to the TB species that are found today in humans, possibly derived from an Asian strain. However, recent studies from the Osmore river valley of southern Perú have identified TB in ancient South American human remains most closely linked to the form that affects pinnipeds (seals and seal lions), suggesting that these sea mammals served as the vector that transferred the pathogen from the Old World to South America (Bos et al 2014). Studies of historic period South American human remains thus become crucial for evaluating the nature of TBhuman co-evolution in the Western Hemisphere. The remains from Tierra del Fuego, due to their location, skeletal evidence of TB, and antiquity, thus become especially important in this regard. Our study was conducted to clarify the chronological placement of the remains, to provide a detailed description of the remains, and to generate genetic information about the pathogen.

\section{Archaeological context}

By approximately 8000 BP, a land bridge connected Tierra del Fuego and the mainland (McCulloch and Morello 2009), which was potentially first used by hunter-gatherers who arrived at least 10,000 years ago (Massone 2003). Beginning in the 16 th and extending into the 18th century $A D$, contact between indigenous groups and Europeans was almost exclusively coastal. According to documentary sources, European exploration of Tierra del Fuego's interior began at the end of the nineteenth century (Borrero 1992, Fugassa and Guichón 2004).

The Myren 1 site is located approximately $14 \mathrm{~km}$ north of Inútil Bay (53 ${ }^{\circ} 14^{\prime} \mathrm{S}-69^{\circ} 28^{\prime} \mathrm{W}$ ), at the northern aspect of a wide glacial valley that connects this cove to the Bay of San Sebastián, located in the Chilean territory north of Tierra del Fuego. Myren 1 is a large 
(approximately $200 \times 150 \mathrm{~m}$ ) archaeological site, positioned on the eastern shore of Banty lagoon. In 1998, Massone and Jackson noted four areas with concentrations of cultural material. A few years earlier, farm workers had found a skull located on the eastern side of the lagoon, $38 \mathrm{~m}$ from the edge of the water (now called Sector 1). Partially buried human remains also were discovered in a deposit of silt near the lagoon (Sector 1), within a flat area near the bay where the herbaceous cover had been partially eroded (Fig. 2). Massone recovered long bones, phalanges, teeth, and fragments of ribs and vertebrae scattered on the silt surface within a radius of up to $20 \mathrm{~m}$ surrounding the buried remains. Both the surface scatter and the buried remains appear to be from the same individual. The skeleton was removed due to its progressive deterioration and dispersal due to a very active erosion front located near the edge of the lagoon. The skeletal remains discovered in situ was in a flexed position, with the upper part oriented towards the southeast. No cultural remains associated with the interment were discovered (Massone \& Jackson 1998). The skull, recovered in 1986, thought to be associated with the same individual, had been culturally modified in the tabular erect style (Guichón 1994; Berón y Luna 2009).

Sector 2, established to further explore site stratigraphy, was located $80 \mathrm{~m}$ east of Sector 1. It is a $31 \times 19 \mathrm{~m}$ flat, irregularly shaped, raised surface with a noticeable concentration of stone artifacts and remains of a guanaco exposed on the eroded silt surface and in the cuts adjacent to the raised area. In January 1999, a 1 × 1 m survey and a $2 \times 2 \mathrm{~m}$ excavation next to the survey region were carried out. In this sector the excavations exposed four natural silt strata containing small freshwater snails. Only Stratum III, situated between 45 and $75 \mathrm{~cm}$ below the surface, contained cultural material: including a cut guanaco epiphysis, a fragmentary stone point tip, and some red pigment. A sample of guanaco bones removed from Level III was radiocarbon dated to $870+70 \mathrm{BP}^{1}$ (Massone et al. 1999). This date, along with the associated material culture links the site to the Selk'nam Culture (Massone ibid).

\section{Material and methods}

The skeleton Myren 1 (\# 30477 curated at the Center for the Study of Southern Man, Instituto de la Patagonia, Universidad de Magallanes, Punta Arenas, Chile) was excavated in 1998. A complete inventory of the remains was conducted, as well as an overall assessment of preservation. Sex estimation was based upon pelvis and skull morphology (Buikstra and Ubelaker 1994). Age at death was estimated by observing the pubic symphysis (Brooks and Suchey 1990) and auricular surface (Lovejoy et al 1985, Falys et al 2006). The AMS radiocarbon dating was performed at the Center for Applied Isotope Studies at the University of Georgia, Athens, Georgia. Sample preparation for isotopic analyses followed standard protocols and procedures (Ambrose 1990). Isotopic analyses

\footnotetext{
${ }^{1}$ Beta 128091 Measured C14 Age 880+/-70 BP; C13/C12 Ratio -19.0* o/oo; Conventional C14 Calibrated results (2 sigma, 95\% probability): cal AD 965 to 1220 (Cal BP 985 to 730)
} 
were carried out at the Stable Isotope Ratio Facility for Environmental Research (SIRFER) at the University of Utah, Salt Lake City, Utah.

Recording pathological lesion of the skeleton followed the criteria suggested by (Aufderheide and Rodriguez Martin (1998), Ortner (2003), Santos and Roberts (2006), Baker et al (1999), Pálfi et al (2012) and Haas et al (2000) for TB. Abnormal bone formation, bone destruction, and lesion distribution were assessed.

Figure 1. Location of Myren 1 in The "Isla Grande" of Tierra del Fuego.

Figure 2. Myren 1, Sector 1. (Massone \& Jackson 1998).

Destructive analyses: The aDNA bone sample from Myren was processed at Arizona State University's (ASU) laboratory designated for ancient DNA work and following protocols to prevent contamination as is standard in the field (e.g. Cooper and Poinar, 2000, Paabo et al. 2004). The ancient DNA laboratory contains a class $10,000-H E P A$ filtered clean room. All personnel wear appropriate personal protective equipment, including a coverall with hood, facemask, shoe covers, double gloves and a face shield. The clean room is UV irradiated after use and every night as well as cleaned with bleach to reduce the potential for contamination by exogenous DNA. The ancient and modern DNA laboratories at ASU conform to a unidirectional workflow to eliminate contamination of post-PCR products into the clean room environment; this includes all personnel, equipment and reagents.

A portion of the vertebral body adjacent to a lesion was excised and rinsed to remove surface contaminants with $1.5 \%$ sodium hypochlorite and sterile water. The bone was pulverized in a SPEX ceramic mill. 50-200 mg of powder were left overnight in extraction buffer, 0.5M EDTA and Proteinase K. The sample was purified alongside extraction blanks with a modified silica protocol (Rohland and Hofreiter 2007).

The MTBC includes several closely related "species" or ecotypes: $M$. tuberculosis, $M$. canettii, M. bovis, M. microti, M. africanum, and M. pinnipedii (Bos et al 2014). Four quantitative PCR (qPCR) assays to test for the presence and quantity of a single-copy and two multi-copy regions within the MTBC DNA were designed using the primers and probes listed in Table 1 (Harkins et al. 2015). The assays target two nearby regions in the beta subunit of the RNA polymerase gene, referred to here as rpoB-1 and rpoB-2, and the multi-copy mobile insertion elements, IS6110 and IS1081, which are considered to be exclusive to the members of the MTBC (Dziadek et al. 2001, Thierry et al. 1990, Eisenach et al. 1990, van Soolingen et al. 1993), although evidence suggests that some mobile elements are present in other mycobacteria (Kent et al. 1995). Nevertheless, these loci have been used to detect tuberculosis in ancient DNA studies (e.g. Salo et al. 1994; Taylor et al. 2007, Müller et al. 2014). Specifically, the IS6110 and rpoB-1 primers/probe sets used here were designed recently and described in Klaus et al. (2010) and Harkins et al. (2015). All qPCR assays employed TaqMan ${ }^{\circledR}$ hydrolysis probe chemistry, which hybridizes a 
probe to a target sequence within the amplicon, releasing fluorescence proportional to the amount of starting DNA template. This process increases the assay's specificity compared to other quantitation technologies, which detect any amplifiable doublestranded DNA, including primer-dimers and non-specific product. The fluorescence signal is recorded as it crosses a threshold during the linear phase at a given cycle number, called the cycle threshold (Ct). The assay's efficiency is determined by testing a dilution series of DNA with known starting copy numbers, called a standard curve. Theoretically, a PCR efficiency of 1 , or $100 \%$, would result in a doubling of product for each cycle, reflected in a slope of the standard curve at -3.32. In other words, sample dilutions that differ by 10 -fold should cross the $\mathrm{Ct} \sim 3.32$ cycles apart.

Ancient samples often contain substances co-extracted with the endogenous DNA (King et al. 2009). Co-extractors negatively affect PCR efficiency (Wilson 1997), which can be determined from the slope of the standard curve. Inhibition in ancient samples is evaluated by including 10-fold dilutions, here 1:10 and 1:100, and examining deviations from the expected Ct values, or $\Delta \mathrm{Cq} .90-110 \%$ efficiency, or a slope of -3.58 to -3.10 of the standards is required to examine the ancient sample results. In the clean room, the reaction was prepared and qPCR plate loaded with 2x Taqman Universal PCR Mastermix, primers, probe and 2 ul sample and sample dilutions in triplicate, each in a 20 ul reaction; the plate remained covered during the addition of the standard 10-fold serial dilutions, which were added in the post-PCR DNA lab. Standard curves for absolute quantitation were created by diluting DNA from Mycobacterium tuberculosis H37rv with known copy numbers ( 1 to $1 \mathrm{e} 05$ copies/ $\mu \mathrm{l})$.

The Myren sample was also sent to the Paleogenetics Laboratory at the Institute for Archaeological Sciences (IAS) at the University of Tübingen, Germany, where targeted enrichment and sequencing (MiSeq 2000) were performed and reported in Bos et al. (2014), Table S1. Quantitative PCR results are discussed below.

Table 1: qPCR primer and probe sequences (final concentrations).

\section{Results}

\subsection{Preservation:}

The Myren 1 skeleton was fairly complete (Fig. 3), although the upper section of the vertebral column, the right arm and some bones of the hands and feet were not recovered. Macroscopically, bone preservation is very good to excellent, with only minor post-depositional alteration of the 4th thoracic vertebrae and the left first rib.

Figure 3. Surviving elements of Myren 1.

4.2. Sex and age of death. This individual's estimated sex was male, through observations of pelvic and cranial morphology (Buikstra and Ubelaker 1994). Age-at -death was estimated to have been between 18 and 23 years, due to incomplete fusion of long bone 
epiphyses (head and greater trochanter of the femora and the proximal tibiae) and the iliac crests. Also evaluated were the pubic symphyses (phases 1-2 of Brooks and Suchey 1990) and auricular surfaces coincident with Figure 6: A \& B (Lovejoy et al, 1985).

\subsection{Pathological changes.}

In a previous paper, Constantinescu (1999) mentioned that bone characteristics of lower thoracic and the first lumbar vertebrae of this skeleton could be suggestive of having been affected by $\mathrm{TB}$, although detailed descriptions or images were not presented. Our observation showed irregular and asymmetrical hypervascularization on the antero-lateral aspect of the bodies of T6 to T10 vertebrae, with small resorptive foci (less than $3 \mathrm{~mm}$ ) and cortical remodeling (Fig. 4). Similar hypervascularized areas are present on the left side of the bodies from T11 to L1. The end plates of the bodies and the neural arches are not affected. No collapsed vertebrae typical of TB were identified, although the body of L1 shows a 15-degree anterior compression of the body, which could have resulted in slight angular kyphosis. The vertebra, as can be seen in Figure 5, showed reduction of the trabecular matrix, probably due to osteopenia, mentioned by Constantinescu (1999).

No non-specific lesions associated with TB were found in other bones, including on the articular surfaces of long bones (Aufderheide and Rodriguez Martin 1998; Ortner 2003), dactiyitis (Teo and Peh 2004), periosteal reactions of rib ends (Kelly and Micozzi 1984; Roberts et al. 1998; Mays et al. 2002; Santos and Roberts 2006) and symmetrical new bone formation in long bones (Assis et al. 2011). Endocranial lesions, mentioned as possibly related to tuberculous meningitis (e.g. Roberts and Buikstra 2003; Giacon, 2008; Pálfi et al. 2012) could not be studied, although facial bones that in some cases could be affected, were normal in this skeleton.

Hypervascularization of vertebral bodies has been suggested to be associated with TB in skeletons from archaeological sites and in documented collections (Baker 1999; Haas et al. 2000; Pálfi et al. 2012). As stated by Pálfi et al. (2012:9) vertebral hypervascularization, endocranial lesions and rib and long bone periosteal reactions may be useful for diagnosis of TB, but especially when these lesions are all associated together. However, vertebral hypervascularization is also associated with the normal developing spine in non-adult and young adult individuals (Baker 1999; Roberts and Buikstra 2003; Pálfi et al. 2012).

Other pathological conditions that could affect vertebral bodies, mainly brucellosis, trauma and neoplasia, have to be considered in a differential diagnosis of TB (e.g. Aufderheide and Rodriguez Martín 1998; Ortner 2003; Pálfi et al. 2012). Vertebral hypervascularization identified in this skeleton seems not to be related to trauma and bone tumors. On the other hand, it is similar to vertebral lesions attributed to brucellosis described by Mutolo et al. (2012), although no lysis of the antero-superior rim of the vertebral bodies described in this disease was observed (Curate 2006; Mays 2007).

Thus, in the young individual studied here with no other bone lesions suggestive of TB, the observed vertebral hypervascularization could be the result of the normal developing spine, 
although infectious diseases as TB or brucellosis cannot be completely discarded as causative. Other methods, such as molecular analyses (see below), are needed to discuss its etiology.

Figure 4. Thoracic 11th (above), 12th (middle) and Lumbar $1_{\text {st }}$ (below) vertebrae of the skeletons from the Myren 1 site, showing circumferential resorptive areas on the left antero-lateral surfaces of the bodies.

Figure 5. Radiographic images of T11, T12 and L1 of the skeletons from Myren 1. No lytic lesions were observed. These vertebrae were apparently affected by osteopenia. Anterior compression of $\mathrm{L} 1$ is clearly visible (below right).

\subsection{Dating:}

An AMS radiocarbon date of the remains (2005, Center for Applied Isotope Studies, University of Georgia) of $640 \pm 20$ years BP (Caliber Rev 7.0.2 Calibration data set: Marine/So Hem. Two Sigma Ranges Cal AD 1445: cal AD 1504) indicates that these remains predate direct European contact with the indigenous people of Tierra del Fuego.

4.5. Diet. The results obtained from SIRFER, in collaboration with other work in progress, suggest a possible mixed diet ( $\mathrm{d} 15 \mathrm{~N}$ col 16.8 and $\mathrm{d} 13 \mathrm{C}$ col -15.7). These values must be considered within the context of the resources available in this region, such as guanaco (Lama guanicoe) and sea lions (Otaria flavescens), which have values of $\mathrm{d} 13 \mathrm{C}$ al -21 and -8 respectively (Borrero et al 2001, Barberena et al .2009). The values for the Myren individual are within an expected range for a hunter-gatherer diet in this area.

\subsection{Biomolecular identification:}

Four qPCRs designed to target MTBC were used to test for the presence of TB DNA. Multiple replicates of the sample showed the presence of rpoB in both the rpoB-1 and rpoB-2 assays; however, neither IS1081 nor IS6110 were detected during the qPCR analyses. The rpoB-1 and rpoB-2 qPCR analyses displayed an overall slope of -3.29 and 3.34, respectively, with the coefficient of correlation $\left(R_{2}\right)$ for the standard curves being $>$ 0.99. All non-template controls were negative. An undiluted (1:1) extract was tested for rpoB-1 on three separate dates wherein every replicate (total 9 of 9) recorded a signal, as well as three replicates each at 1:10 and 1:100 dilutions. In the rpoB-2 assay, the signal was recorded for two (of two) 1:1 replicates. Only one of three 1:10 replicates recorded a signal, thus resulting in a negative result for this dilution, but it is interesting to note that the replicate recorded a higher quantity and $\mathrm{Ct}$ value than all undiluted extracts. No replicates recorded a signal at 1:100.

These qPCR data, presented in Table 2 and shown in Figure 6, suggest inhibition or primer/probe mismatch in the Myren sample extract, which not only affects efficient reactions but also renders the estimates of starting molecules unreliable. For ancient samples, inhibition is not necessarily surprising. Inhibition can be detected by changes in the threshold cycle or slope as compared to an uninhibited reaction or unexpected $\Delta \mathrm{Cq}$ 
values in a dilution series. The potential inhibition in the Myren sample is demonstrated by a consistent difference across qPCR plates in the slant of the amplification curves, as compared to those of the standards or other positive ancient samples (Fig. 6).

Additionally, within the rpoB -1 assay, sample dilutions of the extract showed presence of the gene regions at the same or higher $\mathrm{Ct}$ values than the undiluted extract, further supporting the presence of inhibition. Although only one of three 1:10 replicates recorded a signal for rpoB-2, it occurred higher than the undiluted replicates. Nevertheless, the qPCR assays detect low quantities of the conserved region of rpoB. Unfortunately, the final amplicon size for the rpoB-1 and rpoB-2 is 66 and $70 \mathrm{bp}$, hindering our ability to successfully Sanger sequence the small products. Without sequence data for the qPCR product, we must then consider the concerns of relying on an evolutionarily conserved element such as the rpoB gene (Stadhouders et al. 2010, Yao et al. 2006). Despite its homology in many organisms, rpoB gene sequence-based identification has been shown to be an effective tool to characterize emerging nontuberculous mycobacteria (NTM) and mycobacterial infections because of the high amount of sequence diversity harbored within parts of the gene (Adekambi et al. 2006). However, to target the correct species accurately, primer/probe design must take into account the ever-increasing number of genome projects that produce new sequence data for previously unknown environmental bacteria, including species of NTM.

An additional challenge to molecular paleopathology is that other pathogenic species outside of the MTBC can cause clinical symptoms resembling tuberculosis, namely $M$. kansasii and M. avium. In fact, in tests of our assays, these two species were detected by our rpoB-1 primer/probe, at low levels; with an input of 1E05 known starting copies/ul of M. kansasii or M. avium DNA, approximately 40 and 8 copies were recorded, respectively, underestimating the known value by $99 \%$. These results indicate the rpoB-1 primer/probe set can record signals from closely-related NTM. The rpoB-2 assay, however, was specific to the MTBC. Given what we observe with mismatches in an alignment between the reference genome and other mycobacterial species within the complex present at the 3' end of the primers and probe, any sequence variability or damage at these sites in the ancient template could explain the late, non-exponential qPCR signal. If rpoB sequence information for the Myren sample became available, the high intra-and interspecies variability within the $r p o B$ gene could help refine the classification as a member of the MTB complex, or as one of the pathogenic species causing tuberculosis like clinical outcomes (Adekambi et al. 2003). Independently, DNA from the Myren bone sample was extracted at the Paleogenetics lab at the IAS in Tübingen, Germany, and enriched via insolution capture targeting five gene regions within the $M$. tuberculosis genome. The capture, product was then sequenced; the capture results are reported in Table S1 of Bos et al. (2014). The capture sequence reads map to $<50 \%$ of each targeted region, with a fluctuating range of coverage across each gene, from 0 to over 100x. These coverage values did not meet the threshold criterion used for full genome capture, indicating that the Myren sample does not have adequate DNA preservation. Unfortunately, if an ancient tuberculosis-causing pathogen is present, it is difficult to discern endogenous pathogen DNA from other endogenous but contaminant (myco)bacteria DNA that may have 
hybridized to the probes during enrichment. Improvements in methods may allow further analysis and independent confirmation of the presence of MTBC DNA.

Table 1: Primer and probe sequences used in qPCR screening of skeletal samples Table 2: qPCR results for rpoB-1 and rpoB-2 of Myren extracts and dilution series. Figure 6. qPCR amplification plots. A. rpoB-1 assay, depicting standards (green), inhibited Myren samples and dilutions (purple), and two uninhibited ancient samples (brown and blue). NTCs=yellow. B. rpoB-1 assay depicting late amplification of all Myren samples and dilutions (blue) with standards (purple). C. rpoB-2 assay, Myren= blue. Green=standards.

\section{Discussion and Conclusions}

The extreme south of the American continent has only recently entered conversations about the presence of TB among indigenous peoples prior to direct contact with Europeans (Gómez et al 2003). The results presented here are discussed with regard to the possible presence of tuberculosis in humans during the $14^{\text {Th }}$ and $15^{\text {Th }}$ centuries in this region. The geographically closest evidence of TB in a pre-contact skeleton is recorded in remains recovered from the Salitroso-Basin Inn site in Santa Cruz province, Argentina, 650 km north and dated to between 1224-1380 cal. AD (Goñi et al. 2003/2005; Garcia Guraieb 2006). Locating other possible evidence of pre-contact TB in Patagonia with better preservation is the future agenda. This is important in relationship to other pre-Columbian evidence, e.g. the TB genomes sequenced from the Osmore River Valley, Peru (Bos et al. 2014). At present, it is assumed that this represents the form identified in other South and North American contexts (Roberts and Buikstra 2003; Stone et al 2009). Its relationship to TB documented in the region during the late $19^{\text {th }}$ and early $20^{\text {th }}$ centuries in death certificates from the Salesian Mission in Rio Grande, Tierra del Fuego will be the subject of further inquiry (García Laborde et al 2010). Other hypothesized sources of TB infection for these groups of hunter-gatherers of southernmost South America also need to be explored (Bastida et al 2011).

Two decades ago TB in several otariid pinniped species in Australia and Argentina was first diagnosed (Bernaldelli et al 1996 and Bastida et al 1999). In 2003, molecular studies determined that pinniped TB was caused by a new species described as Mycobacterium pinnipedii, which is now included in the MTBC. This new species could have been responsible for TB in humans and in wild and domestic animals from prehistoric and historic Tierra del Fuego, although its membership in the MTBC should have resulted in strong signals for all three of the qPCR tests performed here. The distribution and mobility of hunter-gatherers and their prey, including ethnographic, archaeofaunal, and ecological data will be considered to assess the source and antiquity of this type of TB, which could be caused by other types of mycobacteria, including $M$. kansasii and M. avium. Its possible relationship to the disease spectrum of other hunter-gatherers in specific geographical regions will also be examined. Finally, further study using targeted enrichment and nextgeneration sequencing could shed light on the relationship between the causative pathogen and modern mycobacteria. 
As emphasized in the introduction, discussions of the nature and spread of infectious diseases such as TB in the Americas requires a consideration of pan-continental patterning and rigorous tests of alternative hypothesis concerning the nature of ancient TB and its relationship to more recent epidemics. This study represents a first step in addressing these issues from the far south of the Western Hemisphere.

Acknowledgements: This research was supported by PICT 01520 (2007-2010), 0385 (2008-2011) and 0575 (2011-2013) of Argentina, FONDECYT 1960027 of Chile, and the United States National Science Foundation (BCS-1063939). We also thank Proyecto de Colaboración Científica Instituto Canario de Bioantropología y Laboratorio de Ecología Evolutiva Humana (FACSO-UNCPBA, 2003-2004), and the authorities of the Instituto de la Patagonia, Universidad de Magallanes, Punta Arenas, Chile for allowing the study of human remains recovered from Myren, along with. Mr. Bernardo Krusell, owner of Estancia Myren 1, for the archaeological work permit, and Patricia I. Palacio for her help with Figure 1.

\section{References}

Adekambi T., Colson P.,Drancourt M., 2003. rpoB-Based Identification of Nonpigmented and Late-Pigmenting Rapidly Growing Mycobacteria. Journal of clinical microbiology 41(12), 5699-5708.

Adekambi, T., Berger, P., Raoult, D. \& Drancourt, M. 2006. rpoB gene sequence-based characterization of emerging non-tuberculous mycobacteria with descriptions of Mycobacterium bolletii sp. nov., Mycobacterium phocaicum sp. nov. and Mycobacterium aubagnense sp. nov. International Journal of Systematic and Evolutionary Microbiology 56, 133-143.

Ambrose, SH. 1990. Preparation and characterization of bone and tooth collagen for isotopic analysis. J Archaeol Sci 17, 431-451.

Arriaza, B. T., Salo W., Aufderheide AC, and Holcomb TA 1995 Pre-Columbian Tuberculosis in Northern Chile: Molecular and Skeletal Evidence. American Journal of Physical Anthropology 98,37-45.

Aufderheide A.C. , Rodriguez Martín C., 1998. The Cambridge Encyclopedia of Human Paleopathology. Cambridge England, University Press.

Assis, A.C.C., Coelho, R. M., Pinheiro, E. da S., Durigan, G. 2011. Water availability determines physiognomic gradiente in an area of low-fertility soils under Cerrado vegetation. Plant Ecology 212,1135-1147.

Baker B.M., 1999 Early manifestations of tuberculosis in the skeleton. In Pálfi Gy, Dutour O, Deák J, Hutás I, eds., Tuberculosis: Past and Present. Golden Book - TB Foundation, Budapest - Szeged, pp. 301-311.

Barberena, R., Zangrando, A., Gil, A., Martínez, G., Politis, G., Borrero, L.A., Neme, G., 2009. Guanaco (Lama guanicoe) isotopic ecology in southern South America: spatial and 
temporal tendencies, and archaeological implications. Journal of Archaeological Science 36, 2666-2675.

Bastida ,R., Loureiro, J., Quse, V., Bernardelli, A., Rodríguez, D., Costa, E. 1999.

Tuberculosis in a wild subantarctic fur seal from Argentina. Journal of Wildlife Diseases 35(4),796-798.

Bastida, R., Quse, V., Guichón, R.A. 2011. La Tuberculosis en grupos de cazadores

recolectores de Patagonia y Tierra del Fuego: nuevas alternativas de contagio a través de la fauna silvestre. Revista Argentina de Antropología Biológica. Volumen 13, Número 1, Páginas 83-95.

Bernardelli, A., Bastida, R., Loureiro, J., Michelis, H., Romano, M., Cataldi, A., Costa, E. 1996. Tuberculosis in sea lions and fur seals from the southwestern atlantic coast. Revue Scientifique et Technique de la Office International des Epizooties 15(3), 985-1005. Berón M., L. Luna 2009 Distribución espacial y cronológica de la deformación craneana tabular erecta en Pampa y Norpatagonia. Comunicaciones, 561-575. En Arqueología de la Patagonia: una mirada desde el último confín. Editores Salemme, M.C., Santiago, F., Álvarez, M., Piana, E., Vázquez, M., Mansur, E., Ed. -Ushuaia: Utopías, Argentina. Borrero, L.A. 1992. El registro arqueológico del Contacto: enfermedad y discontinuidad poblacional. Simposio Encuentro de Dos Culturas. Ed. Centro Cultural General San Martín. Buenos Aires. p. 1-6.

Borrero, L.A., Guichón, R.A., Tykot, R., Kelly, J., Prieto, A., Cardenas, P., 2001. Dieta a partir de isótopos estables en restos óseos humanos de Patagonia austral. Estado Actual y perspectivas. Anales Instituto Patagonia, serie Cs. Hs., vol. 29,119-127. Punta Arena, Chile Bos, K.I., Harkins, K.M., Herbig, A., Coscolla, M., Weber, N., Comas, I., Forrest, S.A., Bryant, J.M., Harris, S.R., Schuenemann V.J., Campbell, T.J., Majander, K., Wilbur, A.K., Guichón, R.A., Wolfe Steadman, D.L., Collins Cook, D., Niemann, S., Behr, M.A., Zumarraga, M., Bastida, R., Huson, D., Nieselt, K., Young, D., Parkhill, J., Buikstra, J.E., Gagneux, S., Stone, A.C., and Krause, J. 2014 Pre-Columbian mycobacterial genomes reveal seals as a source of New World human tuberculosis Nature 514, 494-497.

Brooks, S., Suchey, J.M. 1990 Skeletal age determination based on the os pubis: a comparison of the Ascadi-Nemeskeri and Suchey-Brooks methods. J Hum Evol,5(3), 227238.

Buikstra, J.E., Ubelaker, D.H. 1994. Standards for data collection from human skeletal remains. Arkansas Archaeological Survey Research Series N44. Arkansas, USA.

Casali R. 2013 Conquistando el fin del mundo. La misión La Candelaria y la salud de la población selk'nam, Tierra del Fuego 1895-1931. Rosario: Prohistoria Ediciones. Colección Historia Argentina.

Comas, I., Coscolla, M., Luo, T., Borrell, S., Holt, K.E., Kato-Maeda, M., Parkhill, J., Malla, B., Berg, S., Thwaites, G., Yeboah-Manu, D., Bothamley, G., Mei, J., Wei ,L., Bentley, S., Harris, S.R., Niemann, S., Diel, R., Aseffa, A., Gao, Q., Young, D., Gagneux. S., 2013 Out-of-Africa migration and Neolithic coexpansion of Mycobacterium tuberculosis with modern humans. Nature Genetics 45, 1176-1182.

Constantinescu, F., 1999. Evidencias bioantropológicas para modos de vida cazador recolector terrestre y marítimo en los restos óseos humanos de Tierra del Fuego. Anales del Instituto de la Patagonia (Serie Ciencias Humanas) 27,137-174. 
Cooper A., Poinar, N.H., 2000. Ancient DNA: do it right or not at all, Science 289. 1139. Curate, F., 2006. Two possible cases of brucellosis from a Clarist monastery in Alcacer do Sal, Southrern Portugal . International Journal of Osteoarchaeology 16,453-458. Dziadek J., Sajduda A., and Borun T.M., 2001. Specificity of insertion sequence-based PCR assays for Mycobacterium tuberculosis complex. Int J Tuberc Lung Dis 5, 569-574.

Eisenach, K.D., Cave, M.D., Bates, J.H., Crawford, J.T., 1990. Polymerase chain reaction of a repetitive DNA sequence specific for Mycobacterium tuberculosis. Journal of Infectious Disease 161(977-981).

Falys, C.G., Schultkowski, H., Western, D.A., 2006. Auricular surface aging: Worse than expected?. A test of the revised method on a documented historic skeletal assemblage. American Journal of Physical Anthropology 130:508-513.

Fugassa, M.H., Guichón, R.A., 2004. Transición epidemiológica en Tierra del Fuego: el contacto indirecto y las enfermedades infecciosas entre 1520 y 1850 . Magallania, 32: 99113.

Gagneux, S., 2012 Host-pathogen coevolution in human tuberculosis. Philosophical transactions of the Royal Society of London. Series B, Biological sciences 367, 850-859. Garcia Guraieb, S., 2006. Salud y enfermedad en cazadores recolectores del Holoceno tardío en la cuenca del Lago Salitroso (Santa Cruz). Intersecciones en Antropología 7:3748.

Garcia Laborde P., Suby, J.A., Guichón, R.A., Casali, R., 2010. El antiguo cementerio de la Misión de Río Grande, Tierra del Fuego. Primeros resultados sobre patologías nutricionales, metabólicas e infecciosas. Rev. Arg. Antrop. Biol. 12(1), 57-69. Giacon, M., 2008. Palaeopathology in the Osteological Collection of Anthropological Museum in Padova University: the cases of tuberculosis, Tesis Doctoral (no publicada), Universidad de Padua, Padua, Italia.

Gómez, I., Prat, J., Mendonca de Souza, S.M.F., 2003. Prehistoric Tuberculosis in America: Adding Comments to a Literature Review. Mem Inst Oswaldo Cruz, Rio de Janeiro, Vol. 98(Suppl. I),151-159.

Goñi, R., Bosio, L.A., García Guraieb, S., 2003/2005. Un caso de enfermedad infecciosa en cazadores prehispánicos de Patagonia. Cuadernos del Instituto Nacional de Antropología y Pensamiento Latinoamericano 20, 399-304, Argentina.

Guichón, R.A., 1994 Antropología Física de Tierra del Fuego, caracterización biológica de las poblaciones prehispánicas. Tesis doctoral, Facultad de Filosofía y Letras, Universidad de Buenos Aires. (no publicada). Argentina.

Haas, C.J., Zink, A., Pálfi, G., Szeimies, U., Nerlich, A.G., 2000. Detection of leprosy in ancient human skeletal remains by molecular identification of Mycobacterium leprae. American Journal of Clinical Pathology 114, 428-436 Harkins, K., Buikstra, J.E., Campbell, T., Bos, K.I., Johnson, E.D., Krause, J., Stone, A.C., 2015. Screening ancient tuberculosis with qPCR: challenges and opportunities. Philosophical Transactions of the Royal Society, London, series B 370:20130622. Hershberg, R., Lipatov, M., Small, P.M., Sheffer, H., Niemann, S., Homolka, S., Roach, J.C., Kremer, K., Petrov, D.a., Feldman, M.W., Gagneux, S.m 2008 High functional diversity in Mycobacterium tuberculosis driven by genetic drift and human demography. PLoS biology 6, e311. 
Hershkovitz, I.N., Donoghue H.D., Minnikin, D.E., Maya, H., Lee, O.Y-C., Feldman, M., Galili, E., Spigelman, M., Rothschild, B.M., Bar-Gal, G.K., 2015. Tuberculosis origin: The Neolithic scenario. Tuberculosis Volume 95, Supplement 1, S122-S126.

Kelley, M.A., Micozzi, M. 1984. Rib lesions in chronic pulmonary tuberculosis. Am J Phys Anthropol 65,381-386.

Kent, L., McHugh, T. D., Billington, O., Dale, J. W., Gillespie, S. H., 1995. Demonstration of homology between IS6110 of Mycobacterium tuberculosis and DNAs of other Mycobacterium spp. J Clin Microbiol 33, 2290-2293.

King, C., Debruyne, R., Kuch, M., Schwarz, C. \& Poinar, H. 2009 A quantitative approach to detect and overcome PCR inhibition in ancient DNA extracts. BioTechniques 47, 941-949. Klaus, H.D., Wilbur, A.K., Temple, D.H., Buikstra, J.E., Stone, A.C., Fernandez, M., Wester, C., Tam, M.E., 2010. Tuberculosis on the north coast of Peru: skeletal and molecular paleopathology of late pre-Hispanic and postcontact mycobacterial disease Journal of Archaeological Science Volume 37, Issue 10, 2587-2597

Lalueza-Fox, C., 1995 Recuperación de DNA Mitocondrial y Caracterización de Variabilidad en Poblaciones Antiguas, 1995. Tesis Doctoral, Barcelona: Universitat de Barcelona.

Lalueza-Fox, C., Pérez-Pérez, A., Prats, E., Cornudella, L., Turbón, D., 1997. Lack of founding Amerindian mitochondrial DNA lineages in extinct Aborigines from Tierra del Fuego-Patagonia. Human Molecular Genetics, 6(1), 41-46.

Lovejoy, C.O., Meindl, R.S., Pryzbeck, T., R., Mensforth R.P (1985) Chronological Metamorphosis of the Auricular Surface of the llium: A New Method for the Determination of Adult Skeletal Age at Death. Am. J. Phys. Anthropol. 68, 15-28. Massone, M., Prieto, A., Jackson, D., Prieto, X., Rojas, G., Seguel, R., Borrero L.A. 1999 Hombre temprano y paleoambiente en Tierra del Fuego. Informe final Proyecto Fondecyt №1960027. Santiago, Chile.

Massone, M., 2003. Fell 1 hunters hearths in the Magallanes region by the end of the Pleistocene. In: Miotti, L., Salemne, M., Flegenheimer, N. (Eds.). Where the South Winds Blow. Texas A and M University Press, College Station, pp.153-159.

Massone, M., Jackson, D., 1998. Myren 1, posible campamento de antiguos cazadores. En Massone M., Prieto A., Jackson D., Prieto X., Rojas G., Seguel R., Borrero, L.A., (Eds.), Hombre temprano y paleoambiente en Tierra del Fuego. Informe de avance 20 año. Proyecto Fondecyt №1960027. Santiago- Chile (no publicado).

Mays, S., Fysh, E., Taylor, G.M., 2002. Investigation of the link between visceral surface rib lesions and tuberculosis in a medieval skeletal series from England using ancient DNA. Am J Phys Anthropol, 119,27-36.

Mays, S.A., 2007. Lysis at the anterior vertebral body margin: evidence for brucellar spondylitis? International Journal of Osteoarchaeology 17,107-118.

Mc Culloch, R., Morello, F., 2009. Evidencia glacial y paleoecológica de ambientes tardiglaciales y del Holoceno temprano. Implicaciones para el poblamiento temprano de Tierra del Fuego, Editado por Salemme, M.C., Santiago, F., Alvarez, M., Piana, E., Vásquez, M., Mansur, E., (ed.) Arqueología de Patagonia: una mirada desde el último confín, :119136. Ushuaia: Editorial Utopías. Argentina. 

Mycobacterium tuberculosis complex DNA in human remains from Britain and continental Europe. Am J Phys Anthropol 153(2), 178-189.

Mutolo, M.J.1., Jenny,L.L., Buszek, A.R., Fenton, T.W., Foran, D.R., 2012. Osteological and molecular identification of Brucellosis in ancient Butrint, Albania Am J Phys Anthropol. 2012 Feb;147(2),254-63. Ortner, D.J., 2003, Identification of Pathological Conditions in Human Skeletal Remains Academic Press. USA.

Pääbo, S., Poinar, H., Serre, D., Jaenicke-Despres, V., Hebler, J., Rohland, N., Kuch, M., Krause, J., Vigilant, L., Hofreiter M., 2004. Genetic analyses from ancient DNA. Annu Rev Genet 38,645-679.

Pálfi G, .ODutour, P. Perrin, C. Sola and Albert Zink. 2015. Tuberculosis in evolution. Tuberculosis. Volume 95, Supplement 1, June 2015, Pages S1-S3. Pálfi, G., Z Bereczki , D.J., Ortner, O., Dutour, 2012 Juvenile cases of skeletal tuberculosis from the Terry Anatomical Collection (Smithsonian Institution, Washington, D.C., USA). Acta Biologica Szegediensis 56(1), 1-12.

Resnick, D., Niwayama, G., 1995. Osteomyelitis, septic arthritis, and soft tissue infection: organisms. In: Resnick, D. (Ed.), Diagnosis of Bone and Joint Disorders. Saunders, Edinburgh, pp. 2448-2558.

Roberts, C. A., Boylston, A., Buckley, L., Chamberlain, A., Murphy,E.M., 1998. Rib lesions and tuberculosis: The palaeopathological evidence.Tubercle and Lung Disease 79 (1), 5560 .

Roberts C.A., Buikstra J.E., 2003. The bioarchaeology of tuberculosis: a global view on a reemerging disease. Gainesville, University Press of Florida.

Rohland, N., Hofreiter, M., 2007. Comparison and optimization of ancient DNA extraction. BioTechniques 42(3), 343-352.

Salo, W.L., Aufderheide, A.C., Buikstra, J.E., Holcomb, T.A., 1994. Identification of Mycobacterium tuberculosis DNA in a Pre-Columbian Peruvian Mummy. Proceedings of the National Academy of Science 91(6), 2091-2094.

Santos, A.L., Roberts, C.A., 2006. Anatomy of a Serial Killer: Differential Diagnosis of Tuberculosis Based on Rib Lesions of Adult Individuals From the Coimbra Identified Skeletal Collection, Portugal. American Journal of Physical Anthropology 130,38-49 Santos, A.L., Suby, J.A., 2012. Tuberculosis en retrospectiva: revisión de los conocimientos actuales y su aplicación en el estudio de restos humanos. Cuadernos de Prehistoria y Arqueología de la Universidad de Granada, 22, 127-148.

Stadhouders, R., Pas, S.D., Anber J., Voermans J., Mes T.H.M., Schutten, M., 2010.The effect of primer-template mismatches on the detection and quatification of nucleic acids using the 5'nuclease Assay. J.Mol.Diagn.12, 109-117.

Stone, A.C., Wilbur, A.K., Buikstra, J.E. \& Roberts, C.A. 2009 Tuberculosis and leprosy in perspective. American Journal of Physical Anthropology 140 Suppl 49, 66-94. Stone, A.C., Wilbur, A.K., Buikstra, J.E., Roberts, C.E., 2009. Tuberculosis and leprosy in perspective. Yrbk. Phys. Anthropol. 52,66e94. 
Taylor, G.M., Murphy, E., Hopkins, R., Rutland, P., Chistov, Y., 2007. First report of Mycobacterium bovis DNA in human remains from the Iron Age. Microbiology 153(4),1243-1249.

Teo, H.E., Peh, W.C., 2004. Skeletal tuberculosis in children. Pediatr Radiol. 34(11), 853-60. Thierry, D., Cave, M. D.,Eisenach, K. D., Crawford, J. T., Bates, J. H., Gicquel, B., Guesdon, J. L.,1990. IS6110 an IS-like element of Mycobacterium tuberculosis complex. Nucleic Acids Research 18, 188. van Soolingen, D., de Haas, P.E.W., Hermans, P.W.M,, et al. 1993 Comparison of various repetitive DNA elements as genetic markers for strain differentiation and epidemiology of Mycobacterium tuberculosis. J Clin Microbiol 31, 1987-1995

Wirth, T., Hildebrand, F., Allix-Beguec, C., Wolbeling, F., Kubica, T., Kremer, K., van Soolingen, D., Rusch-Gerdes, S., Locht, C., Brisse, S., et al. 2008 Origin, spread and demography of the Mycobacterium tuberculosis complex. PLoS Pathogens 4, e1000160. (doi:10.1371/journal.ppat.1000160). Yao, J., Munson, K.M., Webb, W.W., Lis, J.T., 2006. Dynamics of heat shock factor association with native gene loci in living cells. Nature 442(7106), 1050--1053. 


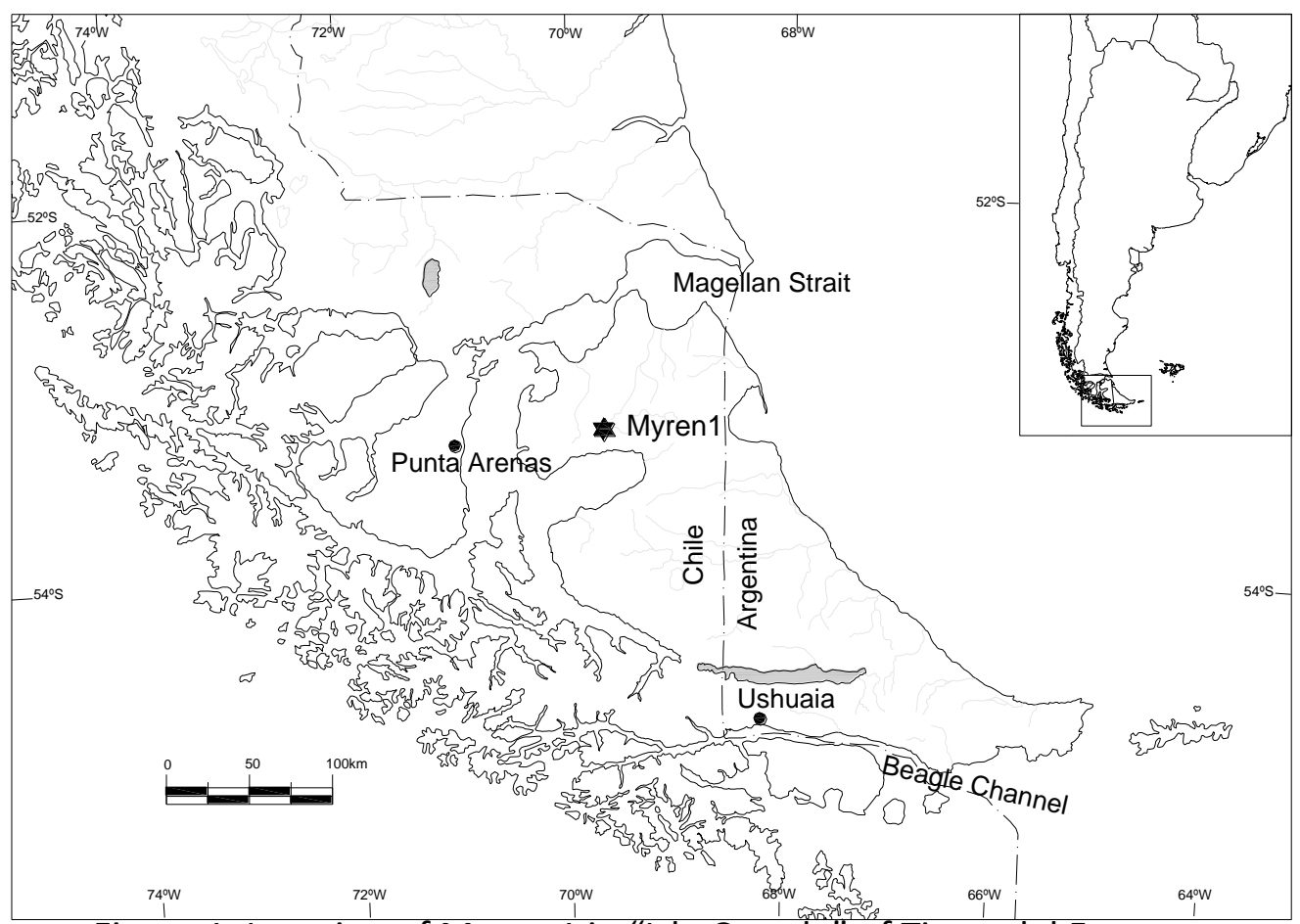

Figure 1. Location of Myren 1 in "Isla Grande" of Tierra del Fuego.

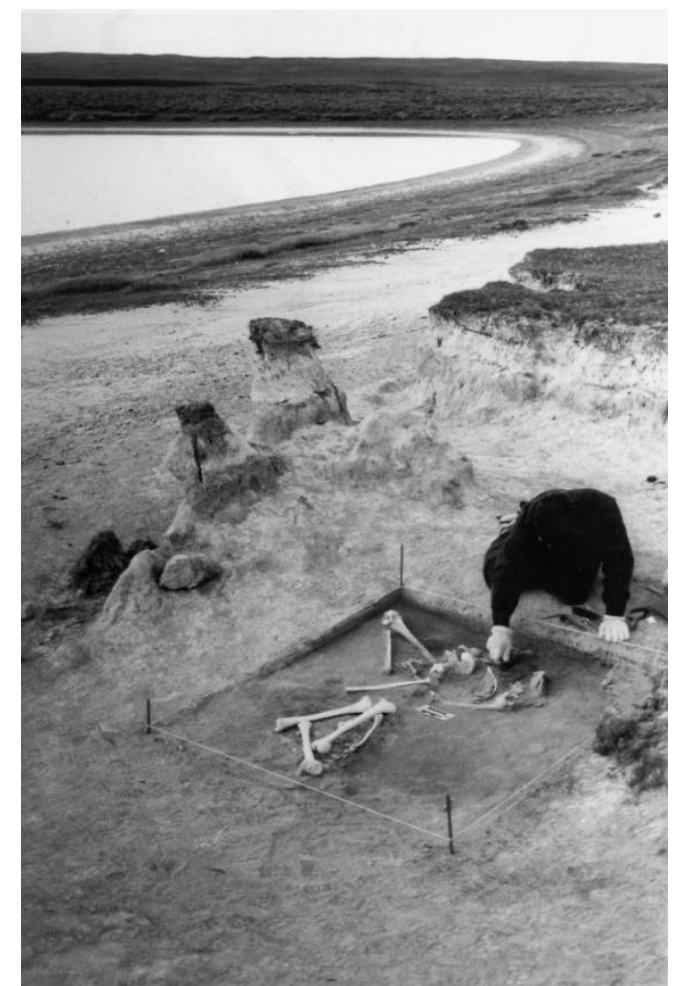

Figure 2. Myren 1 Sector 1. (Massone \& Jackson 1998). 


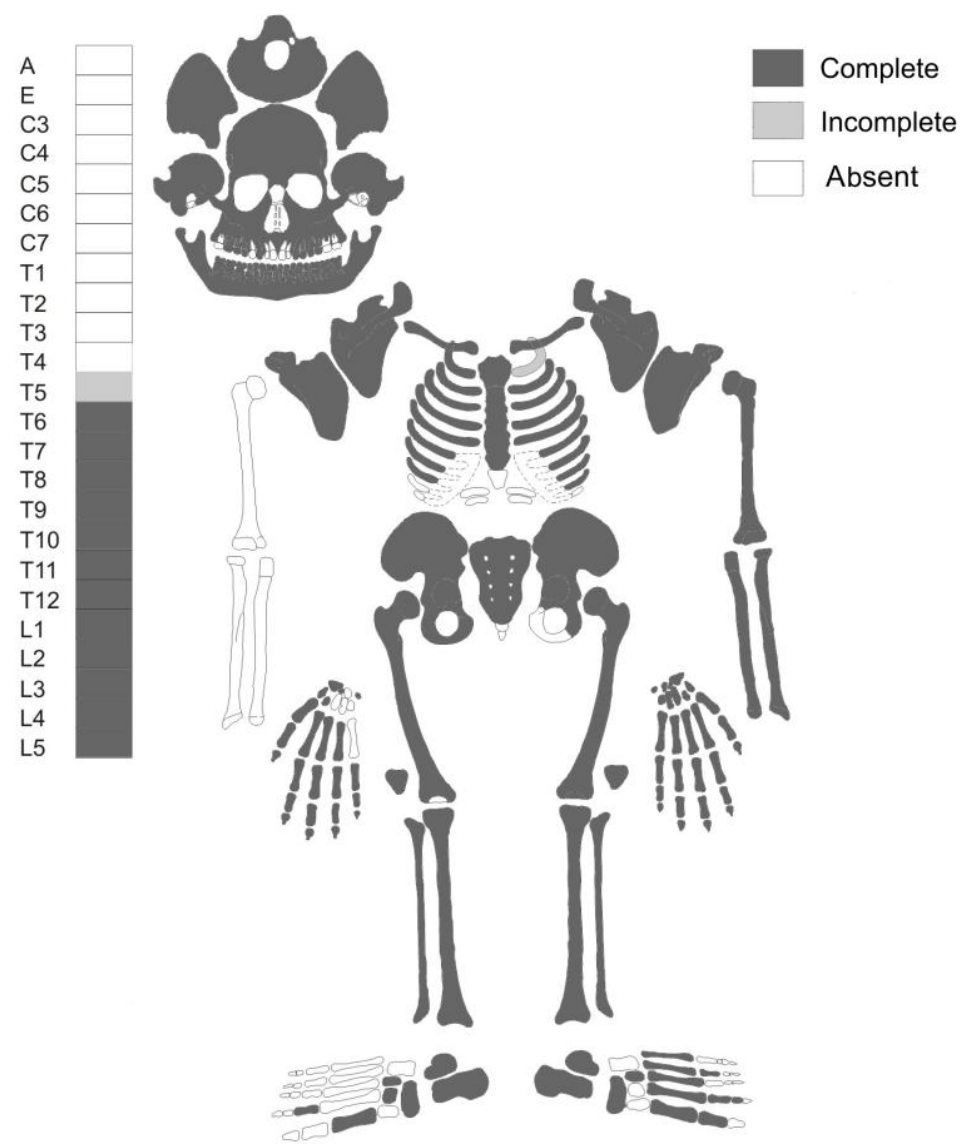

Figure 3. Surviving elements of Myren 1. 


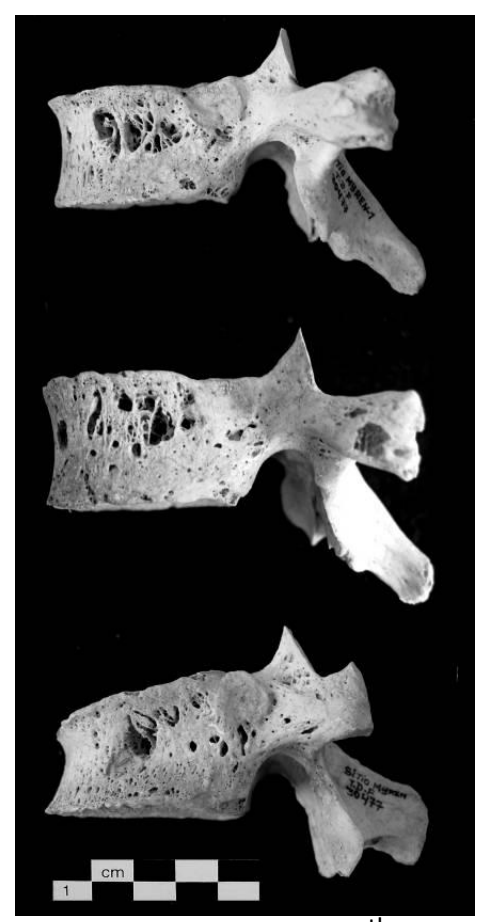

Figure 4. Thoracic $11^{\text {th }}$ (above), $12^{\text {th }}$ (middle) and lumbar $1^{\text {st }}$ (below) vertebrae of Myren 1 site, showing circumferential resorptive areas on left anterior-lateral surfaces of the bodies.

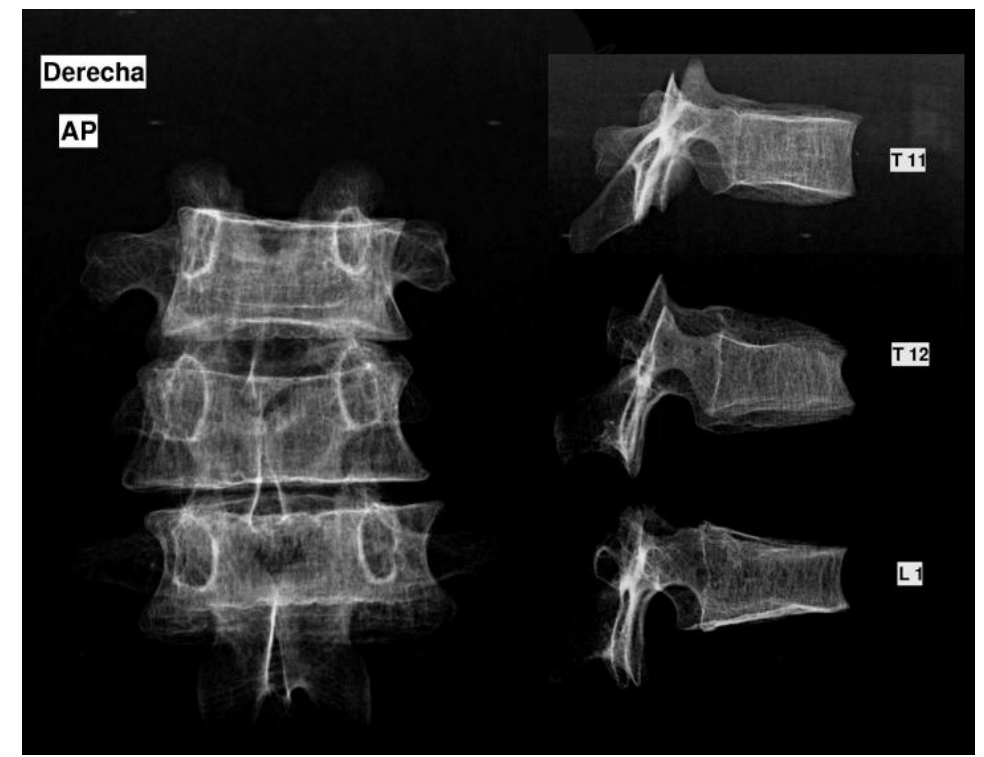

Figure 5. X-ray images of T11, T12 and L1 of Myren 1. No lytic lesions were observed in the images. These vertebrae were apparently affected by osteopenia and anterior compression of L1 is clearly visible (below right). 


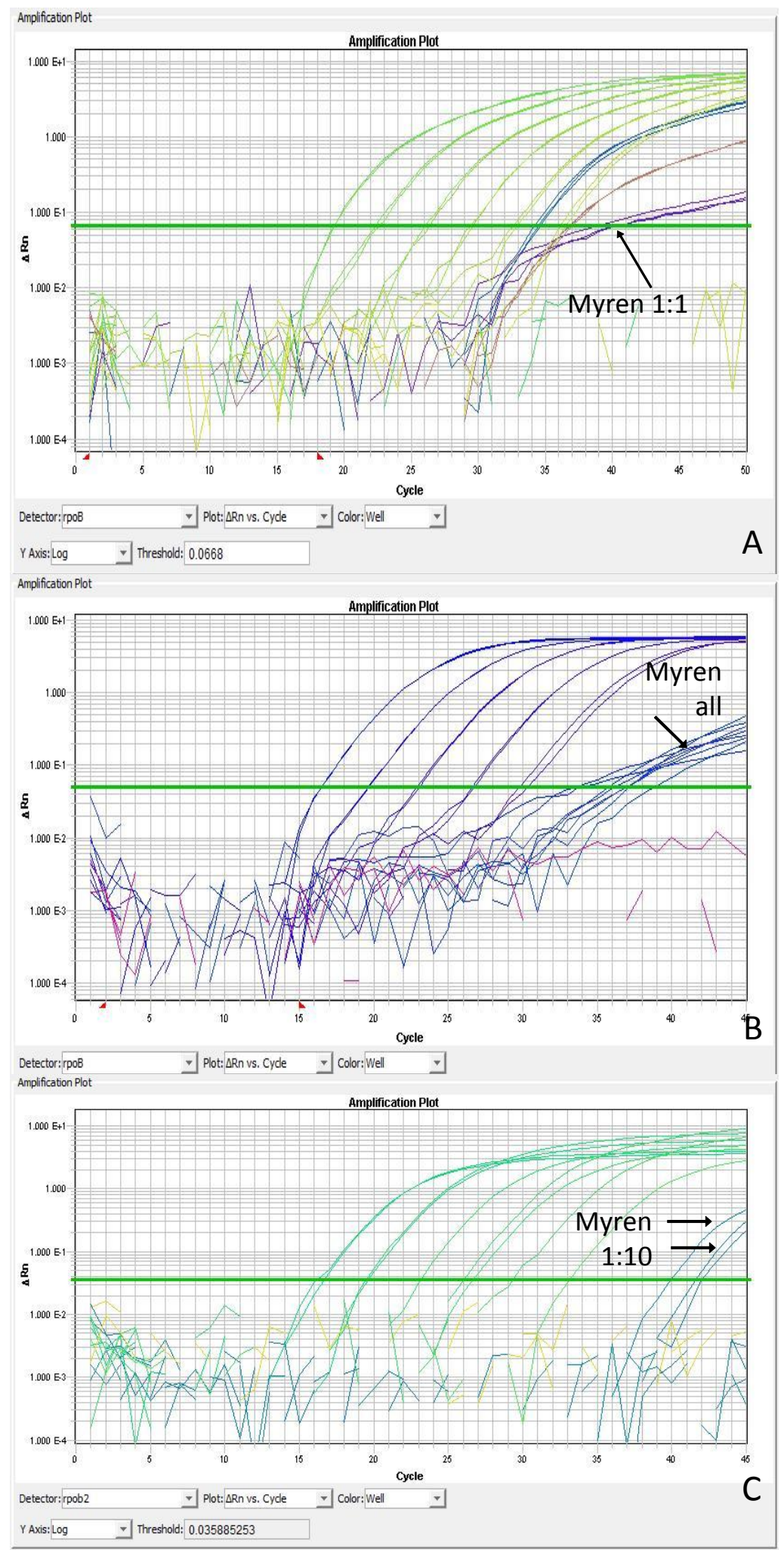

Figure 6. qPCR amplification plots. A. rpoB-1 assay, depicting standards (green), inhibited Myren samples and dilutions (purple), and two uninhibited ancient samples (brown and blue). NTCs=yellow. B. rpoB-1 assay depicting late amplification of all Myren samples and dilutions (blue) with standards (purple). C. rpoB-2 assay, Myren= blue. Green=standards. 


\begin{tabular}{|c|c|c|c|}
\hline $\begin{array}{c}\text { Primer/Prob } \\
\text { e }\end{array}$ & $\begin{array}{c}\text { Final } \\
\text { concentratio } \\
\mathbf{n} \\
\end{array}$ & Sequence (5'-3') & $\begin{array}{c}\text { Amplicon } \\
\text { size (bp) }\end{array}$ \\
\hline IS1081_F & $900 \mathrm{nM}$ & GCACTCCATCTACGACCAG & \multirow{3}{*}{84} \\
\hline $\begin{array}{c}\text { IS1081_Prob } \\
\text { e }\end{array}$ & $300 \mathrm{nM}$ & $\begin{array}{c}\text { 6FAM-ATTGGGCAACAACTGATTCGGCGTCG- } \\
\text { TAMRA }\end{array}$ & \\
\hline IS1081_R & $900 \mathrm{nM}$ & GGGAGTTTGTCGGTCAGAG & \\
\hline IS6110_F & $50 \mathrm{nM}$ & GGGTAGCAGACCTCACCTATGTG & \multirow{3}{*}{63} \\
\hline $\begin{array}{c}\text { IS6110_Prob } \\
\mathrm{e}\end{array}$ & $300 \mathrm{nM}$ & 6FAM-ACCTGGGCAGGGTT-MGBNFQ & \\
\hline IS6110_R & $300 \mathrm{nM}$ & CGGTGACAAAGGCCACGTA & \\
\hline rpoB_F & $50 \mathrm{nM}$ & GGTCGCCGCGATCAAG & \multirow{3}{*}{66} \\
\hline rpoB_Probe & $300 \mathrm{nM}$ & 6FAM-CTCAGCTGGCTGGTG-MGBNFQ & \\
\hline rpoB_R & $300 \mathrm{nM}$ & GGGTTGTTCTGGTCCATGAATT & \\
\hline rpoB2_F & $300 \mathrm{nM}$ & CAACGTCGAGGTGCTATCG & \multirow{3}{*}{70} \\
\hline rpob2_Probe & $300 \mathrm{nM}$ & FAM-TCGCCGCACCGTCACT-NFQMGB & \\
\hline rpoB2_R & $300 \mathrm{nM}$ & CTCCAGGTCCTCGTCCTCA & \\
\hline
\end{tabular}

Table 1 : Primer and probe sequences used in qPCR screening of skeletal samples 


\begin{tabular}{|c|c|c|c|c|c|c|c|c|c|c|c|c|}
\hline Assay & Locus & $\begin{array}{c}\text { Lab } \\
\text { Sample } \\
\text { Name }\end{array}$ & $\begin{array}{c}\text { Dilutio } \\
\text { n } \\
\text { Factor }\end{array}$ & $\begin{array}{l}\text { Quantity } \\
\text { Copies/ul }\end{array}$ & $\begin{array}{c}\text { Mean } \\
\text { Copies/ul }\end{array}$ & $\begin{array}{l}\text { Mean } \\
\text { Copies X } \\
\text { Dilution }\end{array}$ & $\begin{array}{l}\text { Quantity } \\
\text { Copies } \\
\text { Std Dev }\end{array}$ & $\begin{array}{l}\text { Positive } \\
\text { replicates }\end{array}$ & Ct Value & Ct Std Dev & Ct Mean & $\mathrm{Cq}$ \\
\hline aTBassay8 & rpoB1 & AD216.1 & 1 & 0.058000047 & \multirow{3}{*}{0.110536} & \multirow{3}{*}{0.11053572} & \multirow{3}{*}{0.07570621} & \multirow{3}{*}{3 of 3} & 40.63561 & \multirow{3}{*}{0.960075} & \multirow{3}{*}{39.88925} & \multirow{22}{*}{$>3.227$} \\
\hline aTBassay8 & rpoB1 & AD216.1 & 1 & 0.19731332 & & & & & 38.806175 & & & \\
\hline aTBassay8 & rpoB1 & AD216.1 & 1 & 0.076293774 & & & & & 40.225975 & & & \\
\hline aTBassay11 & rpoB1 & AD216.1 & 10 & 1.0434722 & \multirow{3}{*}{1.620302} & \multirow{3}{*}{16.203026} & \multirow{3}{*}{0.71972317} & \multirow{3}{*}{3 of 3} & 34.79895 & \multirow{3}{*}{0.62125} & \multirow{3}{*}{34.25308} & \\
\hline aTBassay11 & rpoB1 & AD216.1 & 10 & 1.3905947 & & & & & 34.383213 & & & \\
\hline aTBassay11 & rpoB1 & AD216.1 & 10 & 2.4268408 & & & & & 33.57707 & & & \\
\hline aTBassay18 & rpoB1 & AD216.2 & 1 & 2.0081918 & \multirow{2}{*}{1.550058} & \multirow{2}{*}{1.5500581} & \multirow{2}{*}{0.647899} & \multirow{2}{*}{2 of 2} & 31.914865 & \multirow{2}{*}{0.624106} & \multirow{2}{*}{32.35617} & \\
\hline aTBassay18 & rpoB1 & AD216.2 & 1 & 1.0919243 & & & & & 32.797485 & & & \\
\hline aTBassay18 & rpoB1 & AD216.2 & 10 & 0.27564484 & \multirow{3}{*}{0.175781} & \multirow{3}{*}{1.7578085} & \multirow{3}{*}{0.09255814} & \multirow{3}{*}{3 of 3} & 34.7916 & \multirow{3}{*}{0.787973} & \multirow{3}{*}{35.58311} & \\
\hline aTBassay18 & rpoB1 & AD216.2 & 10 & 0.09287314 & & & & & 36.367496 & & & \\
\hline aTBassay18 & rpoB1 & AD216.2 & 10 & 0.15882461 & & & & & 35.59023 & & & \\
\hline aTBassay18 & rpoB1 & AD216.2 & 100 & 0.11141992 & \multirow{3}{*}{0.070585} & \multirow{3}{*}{7.058489} & \multirow{3}{*}{0.04080977} & \multirow{3}{*}{3 of 3} & 36.10375 & \multirow{3}{*}{0.970045} & \multirow{3}{*}{36.96132} & \\
\hline aTBassay18 & rpoB1 & AD216.2 & 100 & 0.029800422 & & & & & 38.014133 & & & \\
\hline aTBassay18 & rрoB1 & AD216.2 & 100 & 0.07053434 & & & & & 36.766056 & & & \\
\hline aTBassay18 & rpob2 & AD216.2 & 1 & 0.001929223 & 002321 & 102321 & 2005680 & 2 of 2 & 42.93358 & 03555576 & 4268216 & \\
\hline aTBassay18 & rpob2 & AD216.2 & 1 & 0.002732785 & . & U. & 0.0005002 & 2012 & 42.430744 & טונבכנב.ט & 42.00210 & \\
\hline aTBassay18 & rpob2 & AD216.2 & 10 & 0 & & 0 & & & Undetermined & & & \\
\hline aTBassay18 & rpob2 & AD216.2 & 10 & 0 & & 0 & & 1 of 3 & Undetermined & & & \\
\hline aTBassay18 & rpob2 & AD216.2 & 10 & 0.008372532 & & 0.08372532 & & & 40.8139 & & & \\
\hline aTBassay18 & rpob2 & AD216.2 & 100 & & & & & & Undetermined & & & \\
\hline aTBassay18 & rpob2 & AD216.2 & 100 & 0 & & 0 & & 0 of 3 & Undetermined & & & \\
\hline aTBassay18 & rpob2 & AD216.2 & 100 & & & & & & Undetermined & & & \\
\hline
\end{tabular}

Table 2. qPCR results for rpoB-1 and rpoB-2 of Myren extracts and dilution series. 